\title{
Covid-19: Comparisons by Country and Implications for Future Pandemics
}

Lewis Mehl-Madrona, Bangor (Northern Light Family Medicine Residency) and Orono, Maine (University of Maine and Coyote Institute)

François Bricaire - Université de la Sorbonne - Paris, France

Adrian Cuyugan - Peritus - Manila, The Philippines

Jovan Barac - Peritus - Sydney, Australia

Asadullah Parvaiz - Aspire Technologies - Copenhagen, Denmark

Ali Bin Jamil - Codehoppers - Lahore, Pakistan

Sajid Iqbal - Codehoppers - Lahore, Pakistan

Ryan Vally - BCB - Paris, France

Meryem Koliali - BCB - Paris, France

Mohamed Karim SELLIER - The Innate - London, UK

Address correspondence to Dr. Mehl-Madrona at lewis.mehlmadrona@maine.edu, PO BOX 39, Orono, Maine 04473-0039, USA, Fax No. 01-207-406-5354; telephone 01-808-772-1099.

The authors have no conflict of interest to report.

Patient and Public Involvement. The research questions and outcome measures were those being discussed widely on all news channels. Given that we were all potential patients, we were all involved in the design of the study in that we asked the questions that potential patients were asking in the media.

Keywords: Covid-19 SARSCOV-2 propagation mortality heating, ventilation, and air conditioning (HVAC), vitamin D obesity masking policies crowdedness 
medRxiv preprint doi: https://doi.org/10.1101/2021.05.29.21258056; this version posted June 1, 2021. The copyright holder for this preprint (which was not certified by peer review) is the author/funder, who has granted medRxiv a license to display the preprint in perpetuity.

It is made available under a CC-BY 4.0 International license .

Abbreviations used: SARSCOV-2 = the most recent version of the coronavirus leading to the current pandemic

HVAC - heating, ventilation, and air conditioning

$\mathrm{Cl}$ - Confidence Interval

INSEE - Institut national de la statistique et des études économiques

EUROMOMO - European Mortality Monitoring Project

Statbel - Statistics Belgium

UK - United Kingdom

USA - United States of America

UV - ultraviolet light

GDP - gross domestic product

$\mathrm{AC}$ - air conditioning

JRAIA - Japan Refrigeration and Air Conditioning Association

P-probability

\section{Abstract.}

Background. We set out in this paper to compare Covid-19 results by country to better understand the factors leading to the differing results found internationally.

Methods. We used publicly available large datasets to explore differences by country for Covid-19 mortality statistics. We continuously challenged our projections with reality and numbers from countries around the world, allowing us to refine our models and better understand the progression of the epidemic. All our predictions and findings were discussed and validated from a clinical viewpoint.

Results. While no lockdown resulted in higher mortality, the difference between strict lockdown and lax lockdown was not terribly different and favored lax lockdown. Only one of the top 44 countries had long and strict restrictions. Strict restrictions were more common in the worst performing countries in terms 
medRxiv preprint doi: https://doi.org/10.1101/2021.05.29.21258056; this version posted June 1, 2021. The copyright holder for this preprint (which was not certified by peer review) is the author/funder, who has granted medRxiv a license to display the preprint in perpetuity.

It is made available under a CC-BY 4.0 International license.

of Covid mortality. The United States had both the largest economic growth coupled with the largest rate of mortality. Those who did well economically, had lower mortality and less pressure on their population. Yet they had less mortality than average and less than their neighbors.

Conclusions. Countries with the least restrictions fared best economically. Some of them fared well in terms of mortality, even better than neighboring countries with similar social structures and more severe restrictions. The mortality rates in the USA, however, appeared to suffer from very high obesity rates. Norway and the northern European countries have less strict restrictions from the rest of Europe and had lower mortality rates. COVID-19 mortality was associated with vitamin D status. 
medRxiv preprint doi: https://doi.org/10.1101/2021.05.29.21258056; this version posted June 1, 2021. The copyright holder for this preprint (which was not certified by peer review) is the author/funder, who has granted medRxiv a license to display the preprint in perpetuity. It is made available under a CC-BY 4.0 International license.

Introduction. The data needed to accurately track the transmission and impact of COVID-19 have been hard to collect. The available data do not provide the full picture of the epidemic, are not standardized among countries, and are not always standardized within regions of the same country. Understandably, most governments (and modelers) have focused their efforts on in-country tracking and predictions, making international comparisons difficult. Data are defined and collected differently from country to country, from period to period (and sometimes even within a country at the same period).

Despite these difficulties, mortality from COVID-19 is clearly higher in some countries than in others. Many factors could have a role in this disparity, including differences in proportion of elderly people in a population, general health, accessibility and quality of healthcare, and socioeconomic status. We set out in this paper to compare Covid-19 results by country to better understand the factors leading to the differing results found internationally.

\section{Methods}

We formed a multi-disciplinary team that included an infectious diseases physician, data scientists, and software developers. We continuously challenged our projections with reality and numbers from countries around the world, allowing us to refine our models and better understand the progression of the epidemic. All our predictions and findings were discussed and validated from a clinical viewpoint. We used publicly available large datasets [1-11]

Data Preparation and Analysis. Data was transformed to fit parametric distributions prior to statistical analyses, which were performed with Student's t-test, linear regression and post-hoc tests. Especially for ordinary least squares regression, natural logarithmic transformations were done to remediate normality violations in the standardized residuals. Interpretation on the final model of the regression and analysis of variance were adjusted because of logarithmic transformations. For correlational studies, whether continuous or count data were used, both Pearson's and Spearman's rank correlational tests were done according to the data used. Normality assumptions were not made as we used non-parametric correlation tests to overcome nonlinearity. Most of these normality violations related to bimodal distribution, so running Pearson's correlation tests provided a complete description of the association [12]. Also, power in significance testing were also done to ensure that for some data points that have very minimal number of samples, this was considered that the interpretation of significance is

practically taken into consideration. For cross-correlation of stochastic processes proper 
medRxiv preprint doi: https://doi.org/10.1101/2021.05.29.21258056; this version posted June 1, 2021. The copyright holder for this preprint (which was not certified by peer review) is the author/funder, who has granted medRxiv a license to display the preprint in perpetuity. It is made available under a CC-BY 4.0 International license .

diagnostics were done to ensure the absence of autocorrelation processes that could signal the

delayed copy of itself from its own function of lag. Some weakpoints of the analysis that a limited area (i.e. UV Index, ozone and average daily ridership) were correlated to the national level counts or viceversa with case counts, death counts, density GDP, etc with daily ridership. This is due to limited public data available. All significance levels are set at 0.05 , otherwise specifically stated.

Data were collected at March 28, 2021 for Europe specific analyses and at November 30, 2020, for world comparison analyses.

Excess mortality was assessed using Euromomo charts, in which data points above the red line represent increases in excess mortality. Euromomo charts provide z-scores for excess deaths. This was crossreferenced with the Oxford dataset. The Oxford COVID-19 Government Response Tracker told us when each country imposed lockdowns and other restrictions. Spain imposed a lockdown on 14 March when they had $6300+$ cases and almost 200 deaths. Italy imposed a targeted stay at home order on 23 February and a general population lockdown on 10 March when they had 10k+ cases and 630+ deaths. France imposed a lockdown on 17 March when they had 7.6k+ cases and 140+ deaths. The UK imposed a general population lockdown on 23 March when they had $12 k+$ cases and 360+ deaths. Greece imposed a lockdown on 23 March when they had 650+ cases. Malta imposed restrictions on gatherings on 10 March when they had 5 cases. Portugal imposed a lockdown on 19 March when they had almost 800 cases. Belgium imposed lockdown on 13 March when they had 559 cases and 3 deaths. Restrictions on large gatherings and public places were obtained from the Oxford data and from the Wiki France COVID timeline. Japan imposed a stay at home order on 8 April when they had $4400+$ cases and almost 100 deaths (Wikipedia history of events). Tajikistan imposed a lockdown on 9 May when they had 610+ cases and 20 deaths, while Kazakstan imposed a strict lockdown on 19 March when they had 44 cases and no deaths yet. [April 1st (Week 14) on Euromomo was the highest peak in excess deaths. The Centre for the Mathematical Modeling of Infectious Diseases published estimated $R_{0}$ figures and rates of growth and doubling time per country (https://dataverse.harvard.edu/dataverse/covid-rt).

Environmental relationships were tested using Pearson correlation analysis. The plots and values can be downloaded from https://peritusservices-my.sharepoint.com/:p:/g/personal/adrian peritusservices com/EeQWxQGX-s5PjfC5cbf2Bw8BHxFs9Njywh06FULKsyFyEA?e=XkPYn4. The relative humidity of cities was taken and aggregated into monthly average and quarterly average and then correlated with the national level counts of cases of deaths per country. This was found to be significantly correlated at 0.10 alpha (see link for the plot). UV Index and Ozone levels were taken from the TEMIS satellite dataset, which was cross correlated with the daily national level counts of cases and deaths per country (see https://public.tableau.com/profile/foxyreign\#!/vizhome/UVIndexandOzone/Cross-Correlation). The cross-correlation dashboard based on selected European cities can be viewed at 
medRxiv preprint doi: https://doi.org/10.1101/2021.05.29.21258056; this version posted June 1, 2021. The copyright holder for this preprint (which was not certified by peer review) is the author/funder, who has granted medRxiv a license to display the preprint in perpetuity.

It is made available under a CC-BY 4.0 International license .

https://public.tableau.com/profile/foxyreign\#!/vizhome/UVIndexandOzone/Cross-Correlation. This data does not adjust for average levels of melanin in each country. UV Index and Ozone Cross-Correlation data are found at https://public.tableau.com/profile/foxyreign\#!/vizhome/UVIndexandOzone/CrossCorrelation.

We used Wikipedia pages of selected countries to obtain GINI Index, GDP per Capita, Density, Population count and Average Daily Ridership. We used Accuweather, Weather.com, and Weatherspark.com to obtain data on sunshine and relative humidity as monthly averages. Analysis was done with pair-wise Pearson product-moment correlations. We used 18 European cities, including Paris, Herault, Bouches du Rhone, Loire Atlantique, Nord, Brussels Capital Region, Community of Madrid, Barcelona, MilanRome, Porto Metro Area (North), Lisbon Metro Area, Copenhagen Urban, Stockholm County, Rio de Janeiro State, Sao Paolo State, Miami-Dade County, and New York City. Case counts, death counts, cases per capita and deaths per capita exhibited skewed distributions. Non-parametric methods were used.

Time-series with lag regression was used to compute the mean incubation period for change in percentage of deaths and not the absolute count of deaths. The screenshot of the model summaries are available at https://peritusservices-my.sharepoint.com/:p:/g/personal/adrian peritusservices com/EQhDar3AuGZAhRmUvvrKmyABpfHbSGJ8xdkMs7vnKg0K7Q?e=1K3KHy. Pre-selection of the lag to be included in the lag regression was done using the cross-correlation but the time-series did not undergo pre-whitening nor was it adjusted for seasonality.

Data sources included the UV station data based on TEMIS satellite ozone data, available at https://www.temis.nl/uvradiation/UVarchive/stations uv.php (Cloud-free erythemal UV Index and local solar noon ozone values, date range from 1 Mar to 25 May 2020), COVID-19 Coronavirus Pandemic, Worldometers, date range from 1 Mar to 25 May 2020, and COVID-19 Community Mobility Reports, Google, date range from 1 Mar to 25 May 2020 -

https://www.gstatic.com/covid19/mobility/Global Mobility Report.csv. Selected cities were joined that matched between Google Mobility and TEMIS Satellite datasets. There were 7 cities included Venice, Paris, Madrid, Copenhagen, Bern, Stockholm, and Lisbon. The daily death change percentage has extreme values so any death change percentage above $200 \%$ was replaced, setting the limit to $200 \%$ (i.e. the maximum was 3,600\% Sweden from 2 to $80+$ deaths in just two days!). We ran the $1^{\text {st }}$ iteration of the model using the computed for cross-correlation of available data and picked out the top 3 correlation coefficient values under 0.05 significance:
- UV Index - lag +7 and +11
○ Transit - lag $+11,+17,+24$
- Residential - $\operatorname{lag} 10,17,24$ 
medRxiv preprint doi: https://doi.org/10.1101/2021.05.29.21258056; this version posted June 1, 2021. The copyright holder for this preprint (which was not certified by peer review) is the author/funder, who has granted medRxiv a license to display the preprint in perpetuity.

It is made available under a CC-BY 4.0 International license .

Then we ran the $2^{\text {nd }}$ iteration of the model using the computed for cross-correlation of available data and picked out the highest correlation coefficient values under 0.05 significance:

- UV Index is significant at 0.05

- Transit is not significant

○ Residential is significant at 0.10

Model residuals were tested for normality. We ran final iteration of the model with the above significant independent variables with lag. Model residuals are normal.

Data sources for sunlight included the COVID-19 Coronavirus Pandemic, Worldometer, (accessed on 5 May 2020 at https://www.worldometers.info/coronavirus/ ), Selected cities by sunshine duration, Wikipedia (accessed on 5 May 2020 at https://en.wikipedia.org/wiki/List of cities by sunshine duration, and Selected cities by average temperature, Wikipedia (accessed on 5 May 2020 at https://en.wikipedia.org/wiki/List of cities by average temperature). We used Pearson productmoment correlation and scatterplot visualization.

Average daily ridership of some cities was correlated with counts of cases and deaths where the metro was located using the Google Mobility Cross-Correlation dashboard. Transit stations had a positive correlation at +25 days lag with death count on the following locations, significant at $p<0.05$ for France (0.26), New York State (0.367), and Italy (0.406). Demographics, daily ridership levels, and some national economic scores were used in correlation analysis. The plots may be viewed at https://peritusservicesmy.sharepoint.com/:p:/g/personal/adrian peritus-services com/EU8SkdOVqvdNmgSZ Q-xYABmc3T2WMcACAuW esvUU3gg?e=3asFda. Correlation coefficients for mobility data were derived from cross-correlation analysis done on each variable of the Google mobility dataset with the COVID cases and deaths and can be found at https://public.tableau.com/profile/foxyreign\#!/vizhome/GlobalMobilityReport 15917747268540/Googl eMobilityReportDeaths-A4size.

The technical specifications and software used to calculate all regression models are available at https://peritusservices-my.sharepoint.com/:w:/g/personal/adrian peritusservices com/EQGtrtuLajBlogXUacfwVCUB4XEPH31thzXCycV6eLQA A?e=IZUYIr. Model selection was either based on adjusted $R^{2}$ or $f$-statistic $p$-value using the typical Gaussian linear regression that assumes normal distribution. Log-log normal distribution was used to compute the change in deaths per million with percentage of obesity. Further information is available at https://peritusservices-

my.sharepoint.com/:i:/g/personal/adrian peritus-services com/Eaj5eFSTyfBKtPVYfWPAJIBLXA3FEqDgWUFQZbi3tW3Zg?e=y97F3M. 
medRxiv preprint doi: https://doi.org/10.1101/2021.05.29.21258056; this version posted June 1, 2021. The copyright holder for this preprint (which was not certified by peer review) is the author/funder, who has granted medRxiv a license to display the preprint in perpetuity.

It is made available under a CC-BY 4.0 International license .

The demand for air conditioning of certain countries from 2018 and 2019 was correlated with cases and deaths. See screenshot: https://peritusservices-my.sharepoint.com/:i:/g/personal/adrian peritusservices com/EQZr7N-YIlpDhVogS24eOVQBfOZsqlyjCjZPkzTqHJR3Cw?e=agsm4s. Data sources included https://www.jraia.or.jp/english/World AC Demand.pdf and the Cumulative COVID-19 Our World in Data cases, which showed numbers of deaths and number recovered as of 24 June 2020. We used Pearson product-moment correlation.

Obesity. We used Our World in Data, cumulative count as of 4 Jul 2020 https://github.com/owid/covid-19-data/blob/master/public/data/owid-covid-data.csv and the Central Intelligence Agency of obesity adult prevalence rate (Country Comparison:: Obesity - Adult Prevalence Rate, 2016) - https://www.cia.gov/the-world-factbook/field/obesity-adult-prevalence-rate/countrycomparison. Countries were classified by continent according to their geographic location. Total (cumulative as of 4 Jul 2020) COVID deaths per million dependent variables was transformed using natural logarithmic +1 to eliminate infinity values. We ran a log-normal ordinary least squares regression model using effects coding (sum-to-zero contrast, setting Africa as the reference category) with the following independent variables:

- Obesity prevalence rate nested with the obesity per continent

- Population density

- Aged 70 older

- GDP per capita

- COVID death rate

- Diabetes prevalence

- Female smokers

- Male smokers

- Hospital beds per thousand

- Life expectancy

We ran normality test on the model residuals and checked generalized variance inflation factors for multicollinearity. We ran ANOVA to check the difference in the means and then ran Tukey post-hoc tests to check for pair-wise difference in means. The model coefficients were transformed back using exponents to interpret the model values using $Y$ percent in increase $/$ decrease $=[(\exp ($ beta coefficient -1$) *$ $100]$.

Face Mask Data. We used the COVID Tracking Project, accessed 8 Aug 2020, at https://covidtracking.com/data. Facemask use during the COVID-19 pandemic in the United States was accessed 8 Aug 2020 using https://en.wikipedia.org/wiki/Face masks during the COVID-

19 pandemic in the United States. The COVID tracking project is a time-series dataset that has different variables with daily counts for each state. This dataset was joined with the Wikipedia dataset that classifies the dates if the counts occurred during 'pre-mask', 'post-mask' or 'no law'. We used Quassi- 
medRxiv preprint doi: https://doi.org/10.1101/2021.05.29.21258056; this version posted June 1, 2021. The copyright holder for this preprint (which was not certified by peer review) is the author/funder, who has granted medRxiv a license to display the preprint in perpetuity.

It is made available under a CC-BY 4.0 International license.

poisson regression, zero-inflated Poisson regression, and auto-regressive time-series regression, plus median analysis with random sampling bootstrapped and 5,000 replications of pre-mask vs post-mask and no law.

\section{Patient and Public Involvement}

The research questions and outcome measures were those being discussed widely on all news channels. Given that we were all potential patients, we were all involved in the design of the study in that we asked the questions that potential patients were asking in the media.

\section{Results}

\section{Country Comparisons}

In Figure 1, we present data from Eurostats on excess mortality per country comparing Jan 2020 - Jan 2021 to 2016-2020 periods. We observe that the Scandinavian countries have the least excess mortality. We have selected countries to discuss that encompass the range from minimal to high.

Insert Figure 1 here.

\section{Digging into epidemic phases by country}

\section{Sweden}

Sweden allowed the virus to follow much of its natural course due to the limited restrictions imposed by the government and to its northern lattitude and reduced sun exposure. The actual number of infected cases of Covid-19 can only be extrapolated such that all Infection Fatality Rate (IFR) values are approximations since the true number of infections is unknown. If we account for specific antibodies detected through serology tests and add memory immunity $T$ cells, cross immunity, and cellular immunity, we find values between $14 \%$ and $30 \%$, which puts us in a range between $1,400,000$ and 3,000,000 cases. This results in an IFR or lethality between $0.17 \%$ and $0.34 \%$. 
medRxiv preprint doi: https://doi.org/10.1101/2021.05.29.21258056; this version posted June 1, 2021. The copyright holder for this preprint (which was not certified by peer review) is the author/funder, who has granted medRxiv a license to display the preprint in perpetuity.

It is made available under a CC-BY 4.0 International license .

We note a 3,725 count in excess mortality instead of the 5,420 Covid declared deaths. Some of the extra deaths could be due to those from comorbidities that were attributed to Covid. IFR may actually be lower and would drop to a range between $0.12 \%$ to $0.34 \%$.

Ledberg (2020) explored the epidemic, only looking at the aggressive window from the end of March to early May reaching a count of 4,857, representing a 10.5 \% excess mortality, lower than the 1940/1941 influenza outbreak in terms of mortality/capita. Looking at a wider window gives a better perspective as to actual excess mortality. Covid's effect on a naive population has led to a maximum increased mortality of $8 \%$ compared to influenza. in previous years, assuming no deaths were caused by influenza, the effect of Covid on the population in Sweden where little restrictions were applied was an $8 \%$ increase in death compared to previous years, assuming all excessive death was caused by Covid and none by Influenza.

The 2020 mortality from all causes was $0.48 \%$. Within that the excess mortality related to Covid was $0.04 \%$. This is no comfort for those who lost loved ones, but as immunity builds, future eventual outbreaks are likely to be milder and more can be done to prevent mortality. Over a semester of Covid in Sweden, where the population was recommended to be cautious and large events were cancelled, but also where influenza seemed almost absent, the excess mortality over a semester was $8 \%$ to $10 \%$ more severe than that of previous years in which there were influenza outbreaks.

Sweden is a country that does not benefit from sun, and where, like much of Europe, there is significant obesity. On the other hand, Stockholm, the main city, is less dense than some European capitals.

A the time of writing this paper late March, 2021, Sweden has not been witnessing excess mortality for 6 consecutive weeks.

\section{Denmark}

In Denmark, the epidemic effect on mortality is invisible. Over the first half of 2020 an under-mortality can be observed despite a short lockdown of places. We observed a difference between undermortality and Covid death suggesting a possible Covid death attribution that may be attributed to comorbidities. Excess mortality due to Covid-19 was $-0.01 \%$ 
medRxiv preprint doi: https://doi.org/10.1101/2021.05.29.21258056; this version posted June 1, 2021. The copyright holder for this preprint (which was not certified by peer review) is the author/funder, who has granted medRxiv a license to display the preprint in perpetuity.

It is made available under a CC-BY 4.0 International license .

During the fall of 2020 and the winter of 2021, Denmark did witness a moderate excess mortality but still seems to be spared.

\section{Belgium}

During phase 1 of the epidemic between February and May 2020, Belgium was one of the 3 hardest hit countries in the world despite a severe prolonged lockdown. It declared 9,776 Covid deaths. Excess mortality was 3,993, confirming the same excess in Covid counts with respect to excess mortality as observed for Sweden and Denmark. This difference could be caused by two possible explanations each of which could contribute to this $60 \%$ overcount. Either the Covid situation spared up to 5,783 lives or simply 5,783 deaths occurred with patients who died of comorbidities in the presence of Covid, but actually died of their comorbidities. Belgium has a population of approximately $11,486,000$. Excess mortality in 2020 was around $7 \%$ for the top 3 hardest hit countries during initial epidemic phase. A second phase started in October, 2020, leading again to visible excess mortality until mid-December. As per BeMOMO, since mid- December, there was no notable excess mortality in Belgium. Since February, 2021, in spite of some mortality attributed to Covid, mortality seems to be lower than normally expected.

At the time of writing this paper late March, 2021, Belgium has not observed any excess mortality for 6 consecutive weeks.

\section{France}

France Insee's data provides a similar pattern to that of Sweden with an excess mortality of $6.73 \%$, corresponding to 17,691 people. This is lower than the 29,779 Covid deaths declared by France. If we set aside excess mortality caused by influenza or lockdown and assume that all of that excess mortality is attributed to Covid-19, that figure is still lower by $40 \%$ than the COVID-19 death total, indicating most likely a large comorbidities factor attributed to COVID. Given that May and June 2020 showed undermortality, the excess mortality displayed during the Covid episode is comparable to that of the 2016 2017 influenza outbreak.

When we examine the recent severe Influenza epidemic in 2016-2017 over the months of December 2016 to February 2017 and compare mortality to that of February 2020 to April 2020, the Covid year shows an excess mortality of $1.42 \%$ in one of the 10 hardest countries in the World as per death per million inhabitants. The under-mortalities that followed further confirm the role of comorbidities in 
medRxiv preprint doi: https://doi.org/10.1101/2021.05.29.21258056; this version posted June 1, 2021. The copyright holder for this preprint (which was not certified by peer review) is the author/funder, who has granted medRxiv a license to display the preprint in perpetuity.

It is made available under a CC-BY 4.0 International license.

Covid death counts which could turn out to be $30 \%$ to $60 \%$ of Covid attributed deaths. Having a longer look at history gives us a better insight into what happened in one of the hardest hit countries in the world, but also one that displayed sufficient data transparency because of its structures. In France, 2020 in terms of mortality was slightly milder, or comparable to 2016/2017, 1973, 1997, and 2000 influenza outbreaks and milder than 1969, 1956, 1963, and 1962.

Monthly Death (INSEE data)/Population (Estimate of linear evolution from 42 Million to 67 Million). This suggests a disproportion between the epidemic's impact and the populations' overall reactions which could lead to actions and regulations that are counter-productive on the physical, physiological, and the psychological health of populations, rendering them more fragile against Covid-19.

Ined's recent report indicates for all 2020, we see an excess mortality of 42,000 taking into account population increase and aging, whereas Covid attributed Mortality was slightly below 68,000 . That same report finds that Covid attributed deaths follow similar proportions to mortality amongst different age groups further confirming the role of comorbidities and the importance of a population's general health.

France suffered 2 milder successive phases compared to its initial phase.

At the time of writing this paper, France is still suffering from a moderate excess mortality that maybe subsiding in April as immunity levels rise and weather becomes more favourable.

Portugal, Slovenia, Poland, Czechia, Slovakia, Lituania, Greece, Croatia were spared during the initial phase possibly due to travel restrictions and spring arrival before the outbreak only to suffer a severe outbreak in late fall, 2020, and winter 2021. At that stage, all European countries had adopted community mitigation strategies. These countries are not currently suffering from significant excess mortality.

Latvia and Estonia seems to have faced much of its outbreak in February and March of 2020 and are now catching up with Sweden.

Finland, Iceland and Norway seem to have skipped their turn with moderate or no excess mortality. 
medRxiv preprint doi: https://doi.org/10.1101/2021.05.29.21258056; this version posted June 1, 2021. The copyright holder for this preprint (which was not certified by peer review) is the author/funder, who has granted medRxiv a license to display the preprint in perpetuity.

It is made available under a CC-BY 4.0 International license.

\section{Country Comparisons by Strictness of Lockdown.}

When we compare countries with very different lockdown policies, we see an average of $0.61 \%$ of losses of population in Italy, France, Spain, compared to more lax lockdown policies of Denmark and Austria (0.05\%), and compared with no lockdown policies (Sweden) which showed $0.795 \%$ losses of population. While no lockdown resulted in higher mortality, the difference between strict lockdown and lax lockdown was not terribly different and favored lax lockdown during $1^{\text {st }}$ epidemic phase. During second epidemic phase, Sweden witnessed a negligeable loss of population whereas France, Italy and Spain still witnessed significant mortality. Norway, Finland, and Denmark did not witness any significant excess mortality.

\section{Covid Mortality by Country: a broader look beyond Europe}

Table 1 presents the best 44 performing countries in terms of mortality and the worst 44 countries going from number 104 to number 151 through November, 2020. Only one of the top 44 countries had long and strict restrictions. Strict restrictions were more common in the worst performing countries.

\section{Insert Table 1 here}

Table 2 shows similar data for the individual states in the United States. Three of the top 10 performers in terms of deaths/million had tough restrictions. Five of the 10 worst performers had tough restrictions.

Insert Table 2 here

When we compare the mortality in deaths/million from weeks 1 to 41 for the years 2017, 2018, 2019, and 2020, we can visualize the actual increase in the death rate in 2020 when coronavirus appears compared to prior years. The year 2020 shows approximately 750 deaths/million more than what was found in previous years, which approximates the reported numbers of coronavirus-related deaths for the first 41 weeks of 2020, which was 247,500 excess deaths in the United States. The number of 
medRxiv preprint doi: https://doi.org/10.1101/2021.05.29.21258056; this version posted June 1, 2021. The copyright holder for this preprint (which was not certified by peer review) is the author/funder, who has granted medRxiv a license to display the preprint in perpetuity.

It is made available under a CC-BY 4.0 International license .

deaths/million in 2017 in the first 41 weeks of 2017 were 6,758; in 2018, 6,814; in 2019, 6,792; and in $2020,7,551$.

Table 3 shows that economic growth was possible in some countries despite large increases in mortality. The United States had both large economic loss and the largest rates of mortality. In general, countries with the least restrictions fared best economically. Surprisingly, some countries fared better with less restrictions than neighboring countries with similar social structures and stricter restrictions. These include Uzbekistan compared to Tajikistan, Morocco compared to Egypt, and Belarus compared to Poland and Lithuania. Also, surprisingly, some countries with relatively poor health care capabilities and little capacity to impose restrictions fared well. Guyana's economic improvement was related to discoveries of large oil resources. Benin promoted construction projects to increase their gross domestic product (GDP). The GDP of the United States and Ireland benefited from digital and pharmaceutical sectors. Norway and other northern European countries fared better than other European countries. Their digital economies and oil exports benefited their economy. Egypt redirected its activities from tourism to building infrastructure. Egypt had a curfew, closed restaurants, instructed sick people to stay home, and advised people to eat fruits and vegetables. Vietnam quickly isolated infected clusters. Table 3 relates annual GDP growth (or shrinkage) compared to Covid-19 mortality rates.

Insert Table 3 here.

Figure 2 shows that larger Covid-19 death rates are associated with larger losses in GDP, which is logical.

\section{Insert Figure 2 here.}

Figure 3 presents the best performing countries economically compared to their Covid-19 death rate. As seen with correlation maps those who did well economically, had lower mortality and less pressure on their population. Yet they had less mortality than average and less than their neighbors.

Insert Figure 3 here.

\section{Sensitivity and resistance}


medRxiv preprint doi: https://doi.org/10.1101/2021.05.29.21258056; this version posted June 1, 2021. The copyright holder for this preprint (which was not certified by peer review) is the author/funder, who has granted medRxiv a license to display the preprint in perpetuity. It is made available under a CC-BY 4.0 International license .

Another significant factor in contagion is population resistance -- the presence of a population whom, under normal circumstances would not get infected because of past immunity or other reasons as observed in the past. A healthy population with little obesity, good diet, and adequate levels of vitamin $D$ would be more resilient than an unhealthy population. Children are less likely to contract the virus and less likely to transmit it, so the age of the population matters. For example, in the case study of the French aircraft carrier Charles De Gaulle, in a population of 1,760 who were sharing common dorms, common corridors, and common cantines for a month, 1,043 (59\%) were infected, but the other $41 \%$ tested negative despite having been exposed to significant viral loads repeatedly. This is mostly a male and rather young population. It is possible this resistance may be lower in an older population and potentially higher in women and children. It is also possible that a higher fraction of the adult population may be resistant to the virus under normal exposure due to genetics, cross-immunity, past immunity or other factors. SARS-CoV-2 reactive CD4+ T cells were detected in $40 \%-60 \%$ of unexposed individuals, suggesting cross-reactive T cell recognition between circulating "common cold" coronaviruses and SARSCoV-2 [18].

Recent large gatherings across the world in countries in open-air spaces with few masks did not lead to cluster formation in spite of massive testing further confirming that contamination happens indoors.

Japan, the oldest country in the world with some of the highest density cities and hardly any restrictions was not confronted to any signficant excess mortality. Japan has a superior diet, its elderly do not suffer from vitamin D defficiency, and it has virtually no obesity like much of Asia.

Practically all the large cities strongly affected during phase 1 and for which we have data had a milder phase 2. This is a sign of a possible start to build up sufficient mass immunity and protection to slow the epidemic in these cities. The reverse was true for many cities spared in phase 1 but heavily affected in phase 2 despite identical rules. The observation from London shows that the variant slightly enhances the need for mass immunity; the plateau of the curve in London shows that this complement would have occurred after 2 weeks of circulation. Yet, New York, Belgium, and Madrid were unaffected by the British variant possibly thanks to a higher level of natural immunity acquired at the time the variant arrived. Some cities seem less sensitive to the epidemic; if it is density or urban planning or composition of the population or another permanent fact remains to be determined.

\section{Discussion.}


On a year-to-year analysis, in spite of community mitigation strategies, except for a few countries far north, most countries seemed to catch up and these non-pharmacological interventions do not seem to be driving the epidemic. Their effect is modest compared to population health, urban structure, tourism roaming, obesity, pre-existing cross immunity, vitamin d levels, and weather. [Mehl-Madrona et al.]

Overall, most countries were hit in phases with a comparable outcome in spite of community mitigation strategies. Travel restrictions may have spared some regions in March 2021 only to catch up between October 2020 and March 2021.

Norway, Iceland, and Finland seemed to have been successful with targeted, limited community mitigation strategies. They never issued stay home mandates, used masks in dense closed places and kept much of the schooling system open. Their other limitations were short in time. It is possible that by targeting measures for a short time they had better adherence. It is also possible that vitamin D supplementation policies helped as well as low density lifestyle. One may also consider that these are relatively isolated countries with limited roaming, tourism, and international travel. Beyond Norway and Finland, lax lockdown policies could lead to people spending more time outdoors and receiving more UV radiation which could have improved vitamin D status.

Looking at a broader perspective, there is no indication that strict long measures reduced mortality. The data suggests the opposite.

Countries with the least restrictions fared best economically. Surprisingly, some of them also fared well in terms of mortality, even better than neighboring countries with similar social structures and more severe restrictions. Developing countries with little healthcare capabilities and limited ability to enforce restrictions tended to fare well. Countries with treatments, independent of the type of treatment, fared well. Does this mean that a placebo effect was in operation or is any treatment better than no treatment?

The mortality rates in the USA, however, may have suffered from very high obesity rates. Norway and the northern European countries have less strict restrictions from the rest of Europe and, also, had lower mortality rates. Was this from the longer summer days and earlier cold winter? Egypt fared well despite dense cities, relatively high obesity rates, and high co-morbidities among its older population 
medRxiv preprint doi: https://doi.org/10.1101/2021.05.29.21258056; this version posted June 1, 2021. The copyright holder for this preprint (which was not certified by peer review) is the author/funder, who has granted medRxiv a license to display the preprint in perpetuity. It is made available under a CC-BY 4.0 International license .

(though on average its population is relatively young). Viet Nam fared well by isolating infected clusters in Da Nang and in hospitals. Turkministan chose to completely ignore the epidemic. Like similar countries with low obesity, low density, and a young population, they fared well. Most locations with a substantial first wave mortality and a milder second wave. Extended, prolonged restrictions did not necessarily reduce mortality but did adversely affect economics. Further investigation is needed to tease out the reasons for the wide variations in countries.

Others have pointed to the variations in vitamin D status by country in relation to Covid-19 outcomes. Mitchell [19] notes that SARS-CoV-2, the virus responsible for COVID-19, emerged and started its spread in the Northern hemisphere at the end of 2019 (winter), when levels of 25-hydroxyvitamin D are at their nadir. Also, nations in the northern hemisphere have borne much of the burden of cases and mortality. In a cross-sectional analysis across Europe, COVID-19 mortality was significantly associated with vitamin D status in different populations [20]. The low mortality rates in Nordic countries are exceptions to the trend towards poorer outcomes in more northerly latitudes, but populations in these countries are relatively vitamin D sufficient owing to widespread supplementation campaigns. Italy and Spain are also exceptions, but prevalence of vitamin $D$ deficiency in these populations is surprisingly common. Additionally, black and minority ethnic people-who are more likely to have vitamin D deficiency because they have darker skin - seem to be worse affected than white people by COVID-19. For example, data from the UK Office for National Statistics shows that black people in England and Wales are more than four times more likely to die from COVID-19 than are white people [21]. In Africa, where they spend more times outdoors and they suffer less from obesity, they seem mostly unaffected by Covid with some of the lowest mortality.

How much of the effect of comorbidities were precipitated by Covid? How much of it is disorganization of the health care system leading to death from other causes? The great variability from state to state indicates that a significant portion is due to disorganization as same pathogen would cause similar patterns in a homogeneous society.

De Larochelambert et al. showed that higher Covid death rates are observed in the $\left[25 / 65^{\circ}\right]$ latitude and in the $\left[-35 /-125^{\circ}\right]$ longitude ranges. The national criteria most associated with death rate are life expectancy and its slowdown, public health context (metabolic and non-communicable diseases (NCD) burden vs. infectious diseases prevalence), economy (growth national product, financial support), and environment (temperature, ultra-violet index). Stringency of the measures settled to fight pandemia, including lockdown, did not appear to be linked with death rate. They concluded that countries that already experienced a stagnation or regression of life expectancy, with high income and NCD rates, had the highest price to pay. This burden was not alleviated by more stringent public decisions [22]. 
medRxiv preprint doi: https://doi.org/10.1101/2021.05.29.21258056; this version posted June 1, 2021. The copyright holder for this preprint (which was not certified by peer review) is the author/funder, who has granted medRxiv a license to display the preprint in perpetuity.

It is made available under a CC-BY 4.0 International license.

At a time, where epidemic seems to be subsiding in much of the northern hemisphere possibly thanks to immunity having built up naturally and complemented through immunization of most frail, and highly exposed, at a time where recent literature indicates lasting, reactive cross cellular immunity against variants [23][24], given our finding and those of others, some preliminary conclusions can be made. Strict lockdown does not appear to serve a purpose. Neither does completely ignoring the epidemic. Given our awareness that more pandemics will come, it appears that countries would do well to concentrate efforts on rapid location and quarantining of super-spreading cases, improving indoor ventilation so that air does not circulate from room to room in large buildings, improving ventilation in subways and on public transport systems, providing opportunities for spending time outside, increase fitness, reduce obesity, supplement with vitamin D. All such measures would be efficient for droplet and airborne transmitted diseases and would benefit populations' health by maintaining the strong and strengthening the weak.

\section{Legends for Figures:}

Figure 1. Comparison of excess mortality by country.

Figure 2. Correlation of change in gross domestic product and Covid-19 mortality rates.

Figure 3. Change in gross domestic product and Covid-19 mortality rates in relation to population density.

Table 1. Rankings by country in terms of Covid-19 mortality rates in relation to strictness of restrictions and lockdown policy.

Table 2. Rankings by State in the USA in terms of Covid-19 mortality rates in relation to strictness of restrictions and lockdown policy.

Table 3. Best performing countries by continent in terms of gross domestic product and Covid-19 mortality. 
medRxiv preprint doi: https://doi.org/10.1101/2021.05.29.21258056; this version posted June 1, 2021. The copyright holder for this preprint (which was not certified by peer review) is the author/funder, who has granted medRxiv a license to display the preprint in perpetuity.

It is made available under a CC-BY 4.0 International license.

Contributorship Statement. Drs. Sellier and Bricaire conceived the project and assembled the team to conduct the project. Identification of appropriate databases and statistical analysis of data within those databases was conducted by Drs. Cuyugan, Barac, Parvaiz, Bin Jamil, Iqbal, Vally, Koliali, and Sellier. Interpretation of the findings involved all the authors. Dr. Sellier and Dr. Mehl-Madrona wrote the article.

Competing Interests. None of the authors have any competing interests to disclose.

Funding. This research received no specific grant from any funding agency in the public, commercial or not-for-profit sectors.

Data Sharing. The URLs for all datasets used are provided in the text of the article and are listed as references 1 through 11 .

\section{References}

1. The_Japan_Refrigeraton_and_Air_Conditioning_Industry_Association:, “Word Air Conditioner Demand by Region, The_Japan_Refrigeraton_and_Air_Conditioning_Industry_Association:, Editor. 2020: Tokyo, Japan.

2. Jones, S.P., Imperial College London YouGov Covid 19 Behaviour Tracker, Jones, Sarah P. April 2020 Accessed: July 2020, in Imperial College London YouGov Covid Data Hub, v1.0, YouGov Plc, I.C.L.B.D.A.U.a.Y.P. 2020, Editor. 2020: London, UK.

3. Euromomo, Excess Mortality. 2020.

4. Weather_Atlas, Sunshine Exposure and Weather Temperatures: " https://www.weatheratlas.com/. Accessed: May 2020, in Weather Atlas "Weather forecast and Climate information for cities all over the Globe. Global Weather and Climate data, Weather_Atlas, Editor. 2020.

5. Accuweather, I., Accuweather Inc. 2020.

6. LLC, T.P.a.T., Weather.com.

7. Tropospheric_Emission_Monitoring_Internet_Service, UV station data based on operational TEMIS satellite ozone data, European_Space_Agency, Editor. 2020.

8. Google_LLC., Google COVID-19 Community Mobility Reports. 2020. 
medRxiv preprint doi: https://doi.org/10.1101/2021.05.29.21258056; this version posted June 1, 2021. The copyright holder for this preprint (which was not certified by peer review) is the author/funder, who has granted medRxiv a license to display the preprint in perpetuity.

It is made available under a CC-BY 4.0 International license .

9. Worldometers, COVID-19 Coronavirus Pandemic. 2020.

10. Central_Intelligence_Agency, The World Factbook: “Country Comparison: Obesity - Adult Prevalence Rate," Accessed: July 2020. 2020.

11. The_Atlantic_Monthly_Group, The COVID Tracking Project. 2020.

12. Kowalski, C.J., On the Effects of Non-Normality on the Distribution of the Sample ProductMoment Correlation Coefficient. Journal of the Royal Statistical Society. Series C (Applied Statistics), 1972. 21(1): p. 1-12.

13. Endo, A., et al. Estimating the overdispersion in COVID-19 transmission using outbreak sizes outside China. 202014 April 2020 [cited 202027 August]; Available from: https://cmmid.github.io/topics/covid19/overdispersion-from-outbreaksize.html.

14. Lloyd-Smith, J.O., et al., Superspreading and the effect of individual variation on disease emergence. Nature, 2005. 438(7066): p. 355-359.

15. Bi, Q., et al., Epidemiology and transmission of COVID-19 in 391 cases and 1286 of their close contacts in Shenzhen, China: a retrospective cohort study. Lancet Infect. Dis, 2020. 20: p. 911919.

16. Gomes, M.G.M., et al., Individual variation in susceptibility or exposure to SARS-CoV-2 lowers the herd immunity threshold. medRxiv, 2020: p. 2020.04.27.20081893.

17. de Lima, I.B., et al., Ecotourism community enterprises and ethnodevelopment: modelling the Kalunga empowerment possibilities in the Brazilian savannah. Brazilian Journal of Science and Technology, 2016. 3(1): p. 1-25.

18. Grifoni, A., et al., Targets of T Cell Responses to SARS-CoV-2 Coronavirus in Humans with COVID19 Disease and Unexposed Individuals. Cell, 2020. 181(7): p. 1489-1501.e15.

19. Mitchell, F., Vitamin-D and COVID-19: do deficient risk a poorer outcome? The Lancet Diabetes and Endocrinology, 2020. 8(7).

20. Laird, E., J. Rhodes, and R.A. Kenney, Vitamin D and Inflammation: Potential Implications for Severity of Covid-19. Irish Medical Journal, 2021. 113(5).

21. White, C. and V. Nafilyan, Coronavirus (COVID-19) related deaths by ethnic group, England and Wales: 2 March 2020 to 10 April 2020. 2020, Office for National Statistics: London, UK.

22. De Larochelambert, Q., et al., Covid-19 Mortality: A Matter of Vulnerability Among Nations Facing Limited Margins of Adaptation. Frontiers in Public Health, 2020. 8(782). 
medRxiv preprint doi: https://doi.org/10.1101/2021.05.29.21258056; this version posted June 1, 2021. The copyright holder for this preprint (which was not certified by peer review) is the author/funder, who has granted medRxiv a license to display the preprint in perpetuity.

It is made available under a CC-BY 4.0 International license .

23. Borena et al., Follow-up study in the ski-resort Ischgl: Antibody and T cell responses to SARS-CoV-2 persisted for up to 8 months after infection and transmission of virus was low even during the second infection wave in Austria. Medrxiv February 2021. https://doi.org/10.1101/2021.02.19.21252089

24. Tarke et al., Negligible impact of SARS-CoV-2 variants on CD4+ and CD8+ T cell reactivity in COVID19 exposed donors and vaccinees Biorxiv March 2021.

https://doi.org/10.1101/2021.02.27.433180

25. Eurostats.Excess mortality -2021 https://ec.europa.eu/eurostat/statistics-

ex-

plained/index.php?title=Weekly death statistics\&stable\#Number_of deaths much higher than in_pr evious years 


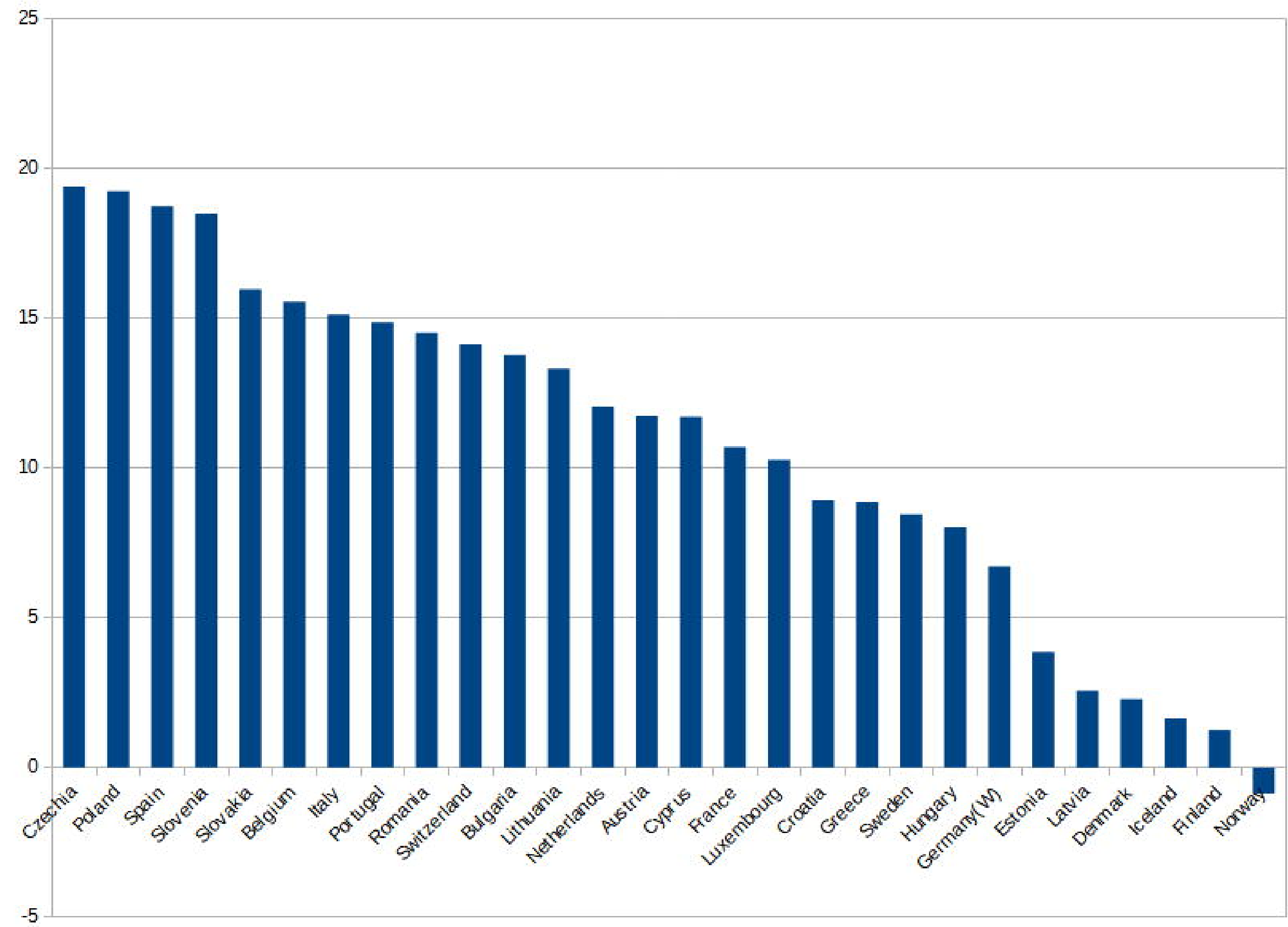




\section{Quarter on Quarter GDP Growth}

Expenditure Approach, Seasonally Adjusted

(Growth Rate Compared to Previous Quarter)

Country

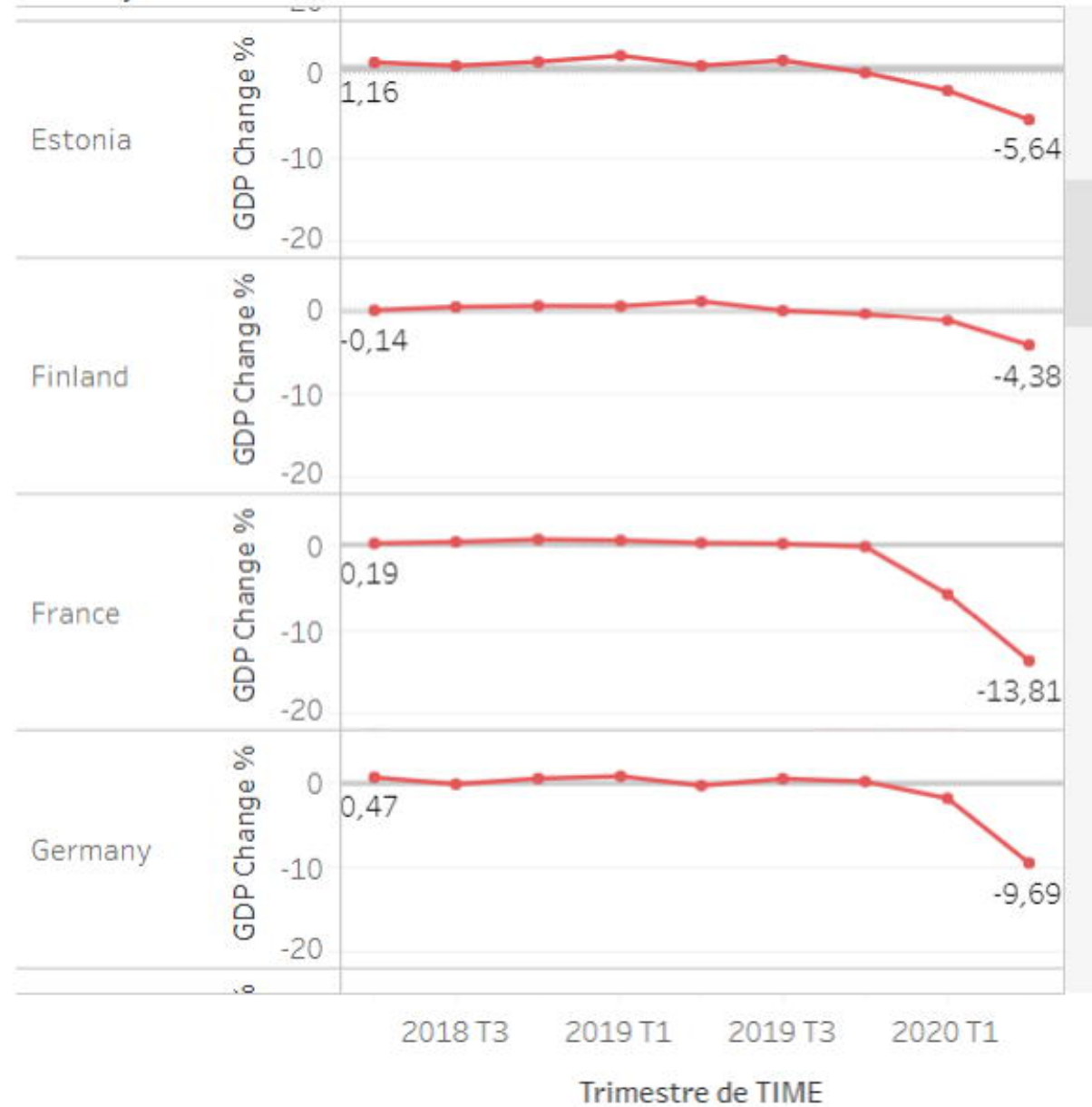

2020 Q2 GDP Growth / COVID Deaths per Million

Bubble sizes indicates population density

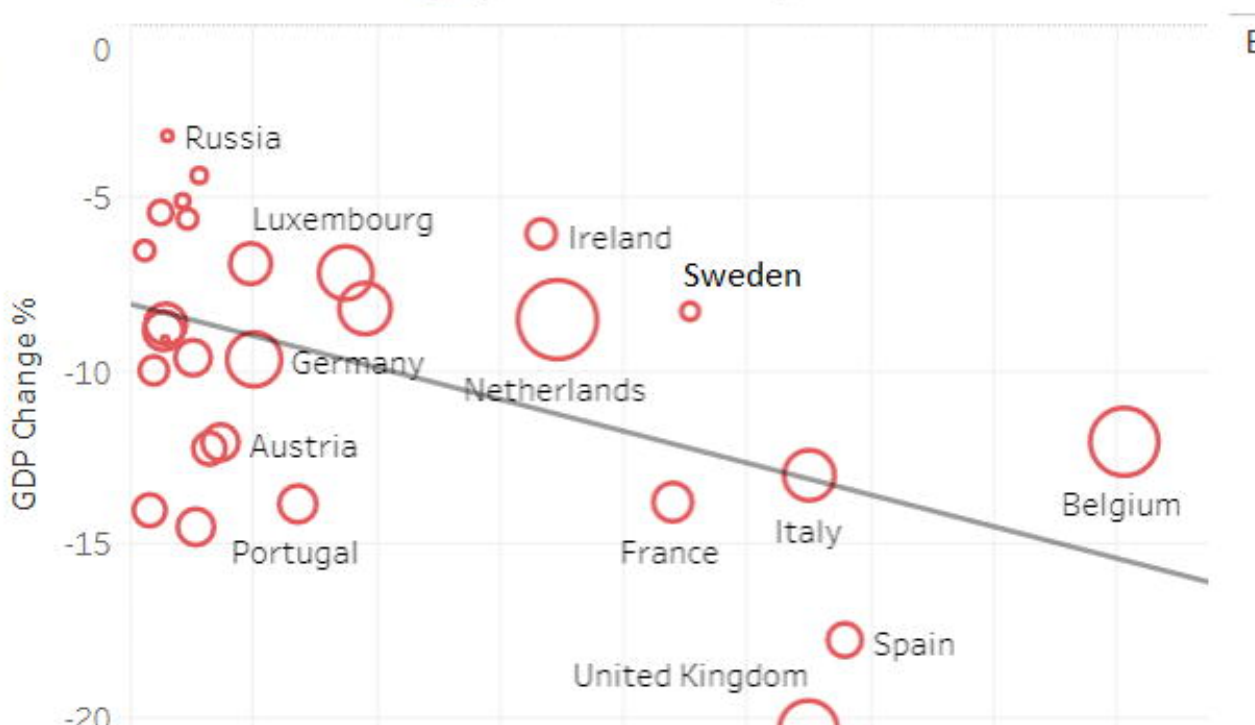

$-20$
100
200 Médiane total_deaths_per_million

continent Country

Europe

COVID Médiane Populati Deaths GDP on Densit per Milli.. Change

\begin{tabular}{l|rrr|}
\hline Austria & 74,2 & $-12,1$ & 106,7 \\
\hline Belgium & 806,7 & $-12,1$ & 375,6 \\
Bulgaria & 20,1 & $-10,0$ & 65,2 \\
Czech Repu.. & 29,8 & $-8,7$ & 137,2 \\
\hline Denmark & 98,6 & $-6,9$ & 136,5 \\
\hline Estonia & 47,5 & $-5,6$ & 31,0 \\
\hline Finland & 57,0 & $-4,4$ & 18,1 \\
\hline France & 440,8 & $-13,8$ & 122,6 \\
Germany & 101,5 & $-9,7$ & 237,0 \\
Greece & 16,8 & $-14,0$ & 83,5 \\
Hungary & 54,2 & $-14,5$ & 108,0 \\
Iceland & 29,3 & $-9,1$ & 3,4 \\
Ireland & 334,2 & $-6,1$ & 69,9 \\
Italy & 551,4 & $-13,0$ & 205,9 \\
Latvia & 12,7 & $-6,5$ & 31,2 \\
Lithuania & 25,7 & $-5,5$ & 45,1 \\
Luxembourg & 175,7 & $-7,2$ & 231,4 \\
Netherlands & 347,3 & $-8,5$ & 508,5 \\
Norway & 43,5 & $-5,1$ & 14,5 \\
\hline Poland & 28,0 & $-8,9$ & 124,0 \\
Portugal & 136,9 & $-13,9$ & 112,4 \\
\hline Romania & 65,1 & $-12,3$ & 85,1 \\
Russia & 31,2 & $-3,2$ & 8,8 \\
Slovenia & 52,0 & $-9,6$ & 102,6 \\
Spain & 580,2 & $-17,8$ & 93,1 \\
Sweden & 454,8 & $-8,3$ & 24,7 \\
Switzerland & 191,3 & $-8,2$ & 214,2 \\
United King.. & 550,7 & $-20,4$ & 272,9 \\
\hline
\end{tabular}

\section{continent}

$\square$ (Tout)

$\square$ Africa

Asia

$\checkmark$ Europe

$\square$ North America

Oceania

South America

negative linear correlation between Q2 GDP Growth and COVID

Deaths per Millions within the European countries. $R=-0.4978329, \mathrm{df}$ $=26, \mathrm{p}$-value $=0.007022(95 \% \mathrm{Cl}-0.7344926-0.1532121)$ 


\section{Q2 GDP Growth / COVID Deaths per Million}

Bubble sizes indicates population density

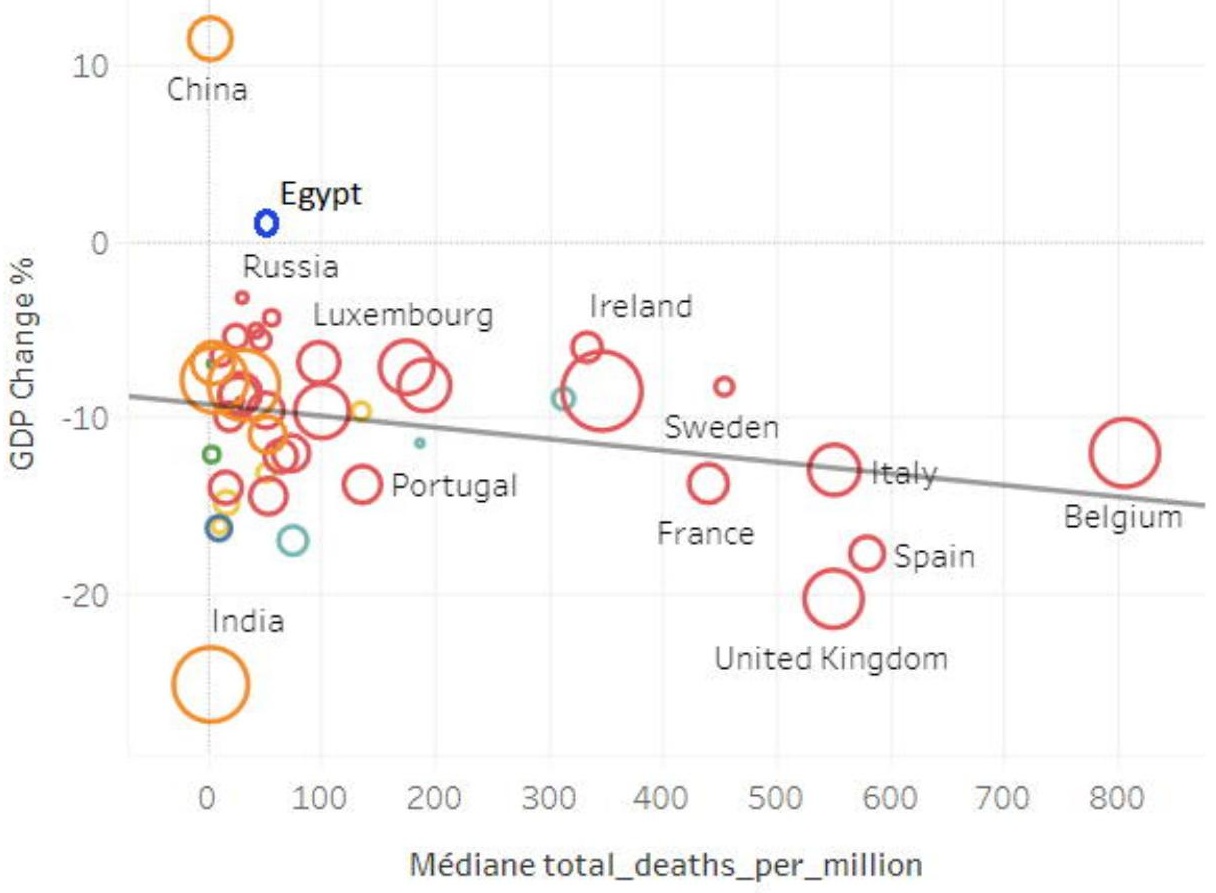


Strict long restrictions
Best Performing countries death/million

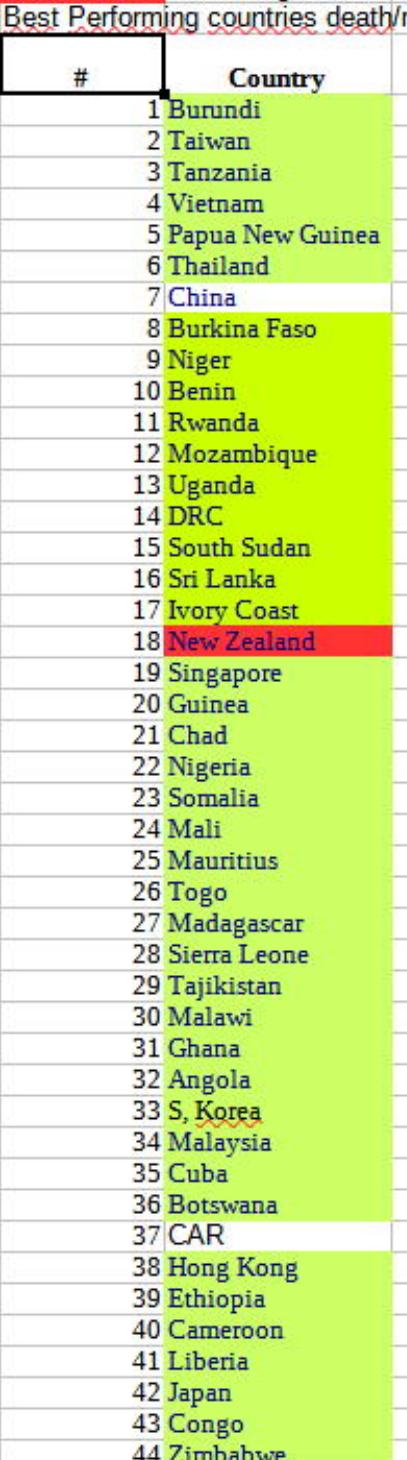
Mild or short restrictions
Worst perforning countries death/million

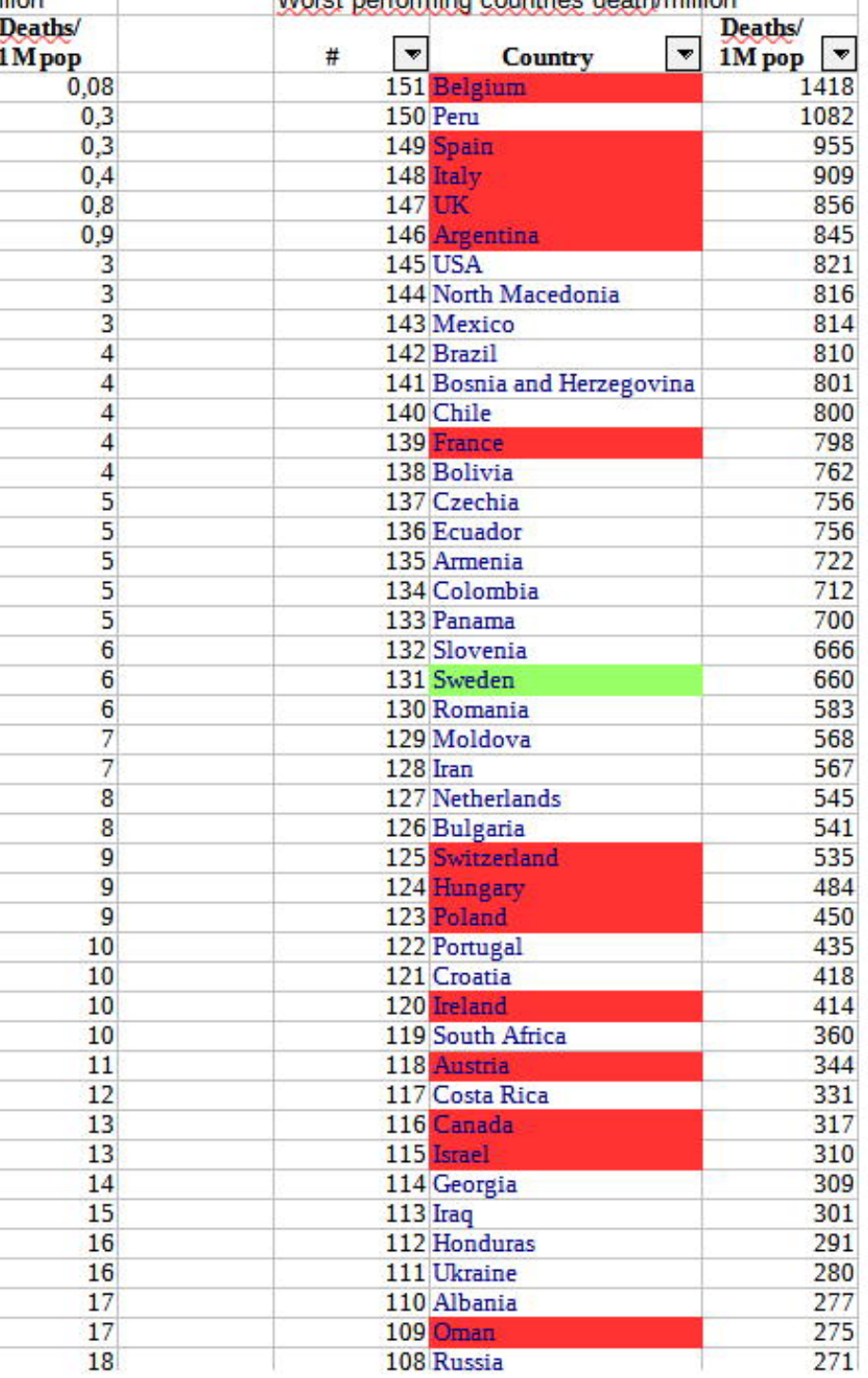


Best performers

Worst performers

Avg death/million

Moderate restrictions

712

Deaths/
$1 \mathrm{M}$ pop

State

Vermont

Maine

Hawaii

Alaska

Oregon

Utah

Wasthington

New Hampshire

Wyoming

West Virginia

Kentucky

Oklahoma

Virginia

California

North Carolina

Idaho

Colorado

Ohio

Nebraska

Kansas

Wisconsin

Montana

Minnesota

Tennessee

Missouri

Nevada
123

167

181

193

238

289

388

406

444

446

456

470

487

521

577

580

589

599

613

623

680

692

714

728

738
501
Avg death/milion

Tough restrictions

1063

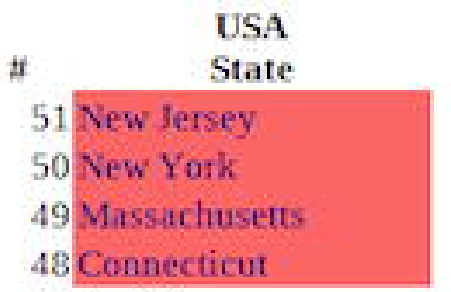

Deaths/

$1 \mathrm{M}$ pop

1958

1793

1583

1443

47 Louisiana

46 Rhode 1sland

1409

1334

1316

1298

1203

1088

1013

982

946

916

909

884

876

873

857

845

814

803

792

792

781 


\section{Best performing countries per continent}

Feom press and interviews of locals

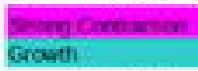

INE dita goweogent-an export-20001213

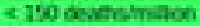

Diala

Country Anmuat Gop growth

Worldometers 1212,2000

\section{continemt}

Arriuat Gop growth

Mortality per malsion

atrica

South Saln

topr

Seris

Cuatemsa

usa

Goyana

Paragay

Turkemstan

Tapoivan

Mrame

Coine

Vetruar

Sentes

4.1

35

2

2

2x:

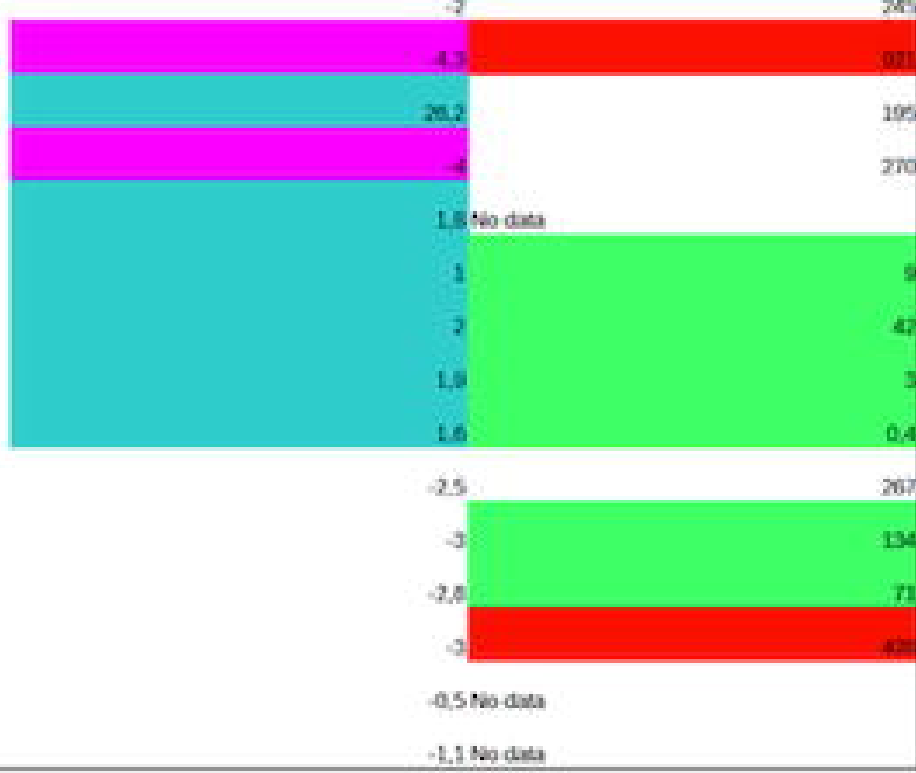

Bedans

Narway

ivelave

Towal

a,5 rodeda

Kariban

-1.1 . Aag dea 